\title{
Development of a Novel Method for Determination of Risperidone in Pharmaceutical Products and its Quality Control Application
}

\author{
Mohamed Raslan ${ }^{1,2}$, Sara $\mathrm{AS}^{2}$, Eslam MS ${ }^{2}$ and Nagwa A Sabri ${ }^{1 *}$ \\ ${ }^{1}$ Department of Clinical Pharmacy, Faculty of Pharmacy-Ain Shams University, \\ Cairo, Egypt \\ ${ }^{2}$ Drug Research Centre, Cairo, Egypt \\ *Corresponding Author: Nagwa A Sabri, Department of Clinical Pharmacy, Faculty \\ of Pharmacy-Ain Shams University, Cairo, Egypt.
}

Received: February 13, 2021

Published: February 27, 2021

(C) All rights are reserved by Nagwa A Sabri., et al.

\begin{abstract}
Background: Risperidone is an antipsychotic drug that is selective to dopamine D2 and serotonin 5-HT2A receptors and used in the management of schizophrenia, and bipolar mania.

Aim: The work objective was to establish a specific, accurate, and sensitive analytical method for the quantification of risperidone in pharmaceutical dosage forms. The method will be used as a quality control tool for testing pre-market and post-market distribution of risperidone products, ensuring that the dosage forms are fulfilling the required labeled amount of the drug.

Methods: Evaluation of risperidone in commercial pharmaceutical products administered in hospitals, community pharmacies, and other health care facilities by the development of a high-performance liquid chromatographic (HPLC) method to add a validated sensitive and selective method to literature methods.

Results: The method showed specificity, sensitivity, and selectivity, and linearity $\left(\mathrm{R}^{2}>0.999\right)$ within concentration range of 0.2 to 6 $\mu \mathrm{g} / \mathrm{mL}$ for dissolution medium USP $(0.1 \mathrm{~N} \mathrm{HCl})$, and 0.1 to $3.4 \mu \mathrm{g} / \mathrm{mL}$ for dissolution medium pH1.2, 4.5, and 6.8. Accuracy percentage within 98 - 102\%, and precision percentage below 2\%. The mean recovery of assayed tablets is $100.113 \%$. In addition, dissolution results meet the required $80 \%$ dissolution limit within 10 minutes.
\end{abstract}

Conclusion: The developed analytical technique is fully validated and applicable for use in the quantitative analysis of risperidone.

Keywords: Risperidone; Analytical Method; Schizophrenia; Bipolar Mania; Pharmacopeia; Dissolution; Validation

\section{Introduction}

Risperidone is an antipsychotic drug that acts as an antagonist for dopamine D2 and 5-HT2A receptors. Risperidone displayed remarkable therapeutic efficacy in the treatment of schizophrenia and bipolar mania in adults [1].

Risperidone is currently one of the most widely used antipsychotic medications for the management of acute schizophrenia and in long-term maintenance. It showed better clinical efficacy in psychotic symptoms treatment than many first-generation antipsychotics [2].

Oral risperidone treatment showed a significant clinical outcome in reduction of autistic disorder associated irritability and other behavioral symptoms in children and adolescents maintained for up to 6 months. The drug showed good tolerability, and 
adverse effects can be clinically managed. Most adverse events are mild to moderate. Some adverse effects like weight gain, hyperglycemia, and somnolence require to be monitored [1].

Clinical studies showed a significant clinical improvement after short-term therapy with risperidone in approximately 50 to $60 \%$ of patients with acute exacerbations and chronic schizophrenia. Risperidone sowed to be as effective as haloperidol and perphenazine in schizophrenia symptoms alleviation. Besides, it shows an advantage over haloperidol in a lower incidence for extrapyramidal side effects [3].

Also, evidence from the literature suggests that risperidone provides a small benefit in treating aggression, psychosis, and agitation in dementia patients. This benefit showed to be statistically significant compared to placebo [4].

Several methodologies for the evaluation of risperidone in pharmaceutical preparations were mentioned in several studies. The techniques include chemiluminescence [5], RP HPLC [6], TLC [7], and visible spectrophotometry [8], HPLC combined with capillary electrophoresis, HPLC-PDA, LC/MS/MS, and NMR spectroscopy [9].

In our work, the presented validated developed method is a specific, sensitive, precise, and accurate for estimation of risperidone in dosage forms and in tablet dissolution test. Analytical method validation was carried out following FDA and ICH guidelines $[10,11]$. Tablet potency testing, dissolution procedures, and criteria were carried out following FDA, BCS Guidelines [12], and United States Pharmacopeia (USP) [13].

Performing in-vitro assay testing, dosage units uniformity and dissolution is an essential step in determining the reliability of the dosage form for the intended use. In addition, assessing dosage form behaviour prior to conducting bioequivalence studies, if necessary. Drug assay should be within 90 to 110 percent of the labeled claim, and the dissolution should be not less than 80 percent of the dissolved drug within 10 minutes to guarantee that risperidone orally disintegrating tablets are valid and safe for use in order to achieve the required therapeutic efficacy.

Routine random drug samples should be picked from the hospital and community pharmacies and exposed to quality control checks to confirm that the formulation retains its integrity and that the quantity of the active ingredient meets the required specification after being subjected to market transport conditions and shelf storage in pharmacies.

Finally, it was impossible to rely on accurate investigations of risperidone in pharmaceutical products unless a valid analytical method was well developed for active substance determination. These routine checks are intended to guarantee that a valid and safe medicinal product is administered to patients in order to achieve the desired therapeutic outcomes and to avoid the incidence of drug toxicity or adverse reactions.

\section{Materials and Methods}

Quality control testing like potency and dissolution testing are performed on a randomly selected samples from the market to ensure that the formulation preserves its integrity and no degradative product formation, and the active ingredient quantity complies with the specified requirements after being exposed to market transport conditions and shelf storage in pharmacies. The objective is to guarantee that patients are given safe and valid drug products in order to achieve the required therapeutic efficacy and to avoid potential drug toxicity or adverse effects.

\section{Materials}

Risperidone USP reference standard. All solvents were of the HPLC grade and were purchased from Merck (Germany). The remaining chemicals used were of AR grade and were bought from Scharlab (Spain).

\section{Analytical methods}

\section{Instrumentation}

The analytical procedures were carried out using BOECO portable pH meter, Sartorius analytical balance, the HPLC Thermo Spectra System 4000 HPLC system, equipped with P4000 Gradient Pump, Autosampler with a $100 \mu \mathrm{l}$ loop and the P1000 UV-Detector. Data processing was carried out by Chromoquest version 4.2 Software. The column used for chromatographic separation was water symmetry C8 with $5 \mu \mathrm{m}$ particles $150 \mathrm{~mm} \times 4.6 \mathrm{~mm}$.

The eluting solvent was vacuum-filtered via a $0.45 \mu \mathrm{m}$ membrane filter and degassed with Sonication prior to use. Water was purified by the water purification system ELGAPURE (England). 


\section{Chromatography conditions}

The eluting solvent consisted of 0.1\% TFA: acetonitrile (70:30 $\mathrm{V} / \mathrm{V}$ ), with a flow rate of $1 \mathrm{ml} /$ minute. Chromatographic peaks have been monitored at $280 \mathrm{~nm}$. Sample analysis was conducted at room temperature, and the injection volume was set at $50 \mu \mathrm{L}$.

Preparation of stock and standard solutions

A $100 \mu \mathrm{g} / \mathrm{ml}$ master solution of risperidone was prepared by weighing $10 \mathrm{mg}$ of risperidone standard into a $100 \mathrm{ml}$ volumetric flask and dissolving $70 \mathrm{ml}$ of methanol. The final volume was completed with methanol. $10 \mathrm{ml}$ aliquot from the standard master solution of risperidone were transferred using A-grade pipettes into a $100 \mathrm{ml}$ volumetric flask and solution were made up to volume with methanol to obtain a solution containing $10 \mathrm{ug} / \mathrm{ml}$. Aliquots were transferred from this solution to a $10 \mathrm{ml}$ volumetric flask. After that the solutions were completed to volume with mobile phase to obtain concentrations of 0.2 to $6 \mu \mathrm{g} / \mathrm{ml}$.

\section{Method validation}

The validation of the in-house HPLC method was carried out following ICH guidelines.

\section{Specificity}

Specificity means that method of analysis is capable of determining the target analyte in the presence of all potential impurities. Stress studies were conducted at a concentration of $4 \mu \mathrm{g} / \mathrm{mL}$ of risperidone active substance and formulated tablet samples to indicate stability and specificity of the method of analysis developed. Intended drug degradation was done under heat stress conditions (exposed at $85^{\circ} \mathrm{C}$ for 1 hour), acidic condition ( $1 \mathrm{~N} \mathrm{HCl}$ for 1 hour at $\left.85^{\circ} \mathrm{C}\right)$ and Alkaline condition ( $1 \mathrm{~N} \mathrm{NaOH}$ for 1 hour at $\left.85^{\circ} \mathrm{C}\right)$.

\section{Linearity}

Linearity of the analytical method was studied by preparing triplicates of standard solutions of the target analyte at eight concentration levels from 80 to $120 \%$ i.e. Concentrations ranging from 0.2 to $6 \mu \mathrm{g} / \mathrm{ml}$ for USP dissolution condition, and from 0.1 to 3.4 $\mu \mathrm{g} / \mathrm{ml}$ for dissolution conditions $\mathrm{pH} 1.2,4.5$, and $6.8[10,11]$.

\section{Precision}

Precision is the evaluation of intra-day variability in results obtained at three concentrations, with nine measurements on the same day. precision is expressed by calculated RSD percent $[10,11]$.
Detection Limit (LOD) and quantitation limit (LOQ)

They are the analyte concentrations that would yield signal-tonoise ratios of 3 for LOD and 10 for LOQ respectively. Detection and quantitation limits were determined by the regression lines $y$-intercepts standard deviation and the calibration slope $[10,11]$.

\section{Estimation of risperidone in pharmaceutical dosage form}

To determine the assay of risperidone in orally disintegrating tablet (labeled claim: 2 mg risperidone) not less than 13 orally disintegrating tablets were weighed and transferred to a $250 \mathrm{ml}$ volumetric flask. $150 \mathrm{ml}$ of diluent (Methanol: $0.1 \mathrm{~N} \mathrm{HCl} \mathrm{40:60)} \mathrm{were}$ added. Sonication with intermittent shaking was performed for 30 minutes. Then the flask was left to cool at room temperature. The volume was made up with diluent, and nylon filter $(0.45 \mu \mathrm{m})$ was used in solutions filtration. $50 \mu \mathrm{l}$ of the prepared samples were injected into HPLC-UV in triplicates. Risperidone UV detection was determined at $280 \mathrm{~nm}$. Drug concentrations were estimated by comparing sample chromatographic response with that of the standard.

Estimation of risperidone content uniformity in pharmaceutical dosage form

To determine the content uniformity of risperidone in tablets (labeled claim: $2 \mathrm{mg}$ risperidone) ten orally disintegrating tablets were weighed and transferred each one individually to a $100 \mathrm{ml}$ volumetric flask. $50 \mathrm{ml}$ of $0.1 \mathrm{~N} \mathrm{HCl}$ was added. Sonication with intermittent shaking was performed for 30 minutes at $40 \mathrm{oC}$. Then the flask was left to cool at room temperature. The volume was made up with diluent, and nylon filter $(0.45 \mu \mathrm{m})$ was used in solutions filtration. $50 \mu \mathrm{l}$ of the prepared samples were injected into HPLC-UV in triplicates. Risperidone UV detection was determined at $280 \mathrm{~nm}$. Drug concentrations were estimated by comparing sample chromatographic response with that of the standard.

In-Vitro dissolution testing determination of risperidone in pharmaceutical dosage form

Procedures of dissolution testing were applied on 12 orally disintegrating tablets under USP dissolution medium $0.1 \mathrm{~N} \mathrm{HCl}$ and media pH 1.2 , 4.5, 6.8 using UPS apparatus Type II at $50 \mathrm{rpm}$ speed for $0.1 \mathrm{~N} \mathrm{HCl} \mathrm{USP} \mathrm{medium} \mathrm{and} 75 \mathrm{rpm}$ speed for $\mathrm{pH} 1.2,4.5$ and 6.8 media as follows:

- The above-mentioned dissolution conditions were carried out in six vessels by placing six orally disintegrating tab- 
lets (one orally disintegrating tablet in each vessel). After 5 , $10,15,20,30,45$ and 60 minutes of dissolution, five $\mathrm{ml}$ of each sample were withdrawn and $5 \mathrm{ml}$ of blank (dissolution media) were added to replace this withdrawn volume and achieve a constant dissolution media volume $(500 \mathrm{ml})$ for USP medium and (900 ml) for pH1.2, pH4.5, pH6.8.

- The withdrawn $5 \mathrm{ml}$ was added in a coded labeled test tube at each sampling interval and then filtered through a (PTFE $0.45 \mathrm{~mm}$ ) syringe membrane filter.

- On a further six orally disintegrating tablets, the previously mentioned procedures were repeated.

- The filtered samples were then injected into the HPLC-UV for drug quantification at $280 \mathrm{~nm}$.

\section{Results}

Risperidone quantification was done by reverse phase HPLC using an eluting solvent consisting of 0.1 percent TFA pH 3: acetonitrile (70: $30 \mathrm{~V} / \mathrm{V})$. The eluting solvent was filtered using a nylon membrane filter (pore size $0.45 \mu$ ) and degassed for 10 minutes on sonicator. $\mathrm{A} \mathrm{C}_{8}$ column (Waters Symmetry 150X4.6 mm, particle size $5 \mathrm{um}$ ) was used to achieve chromatographic separation, the eluting solvent flow rate was $1 \mathrm{ml} / \mathrm{min}$. Parameters of system suitability, such as theoretical plates, were above 4000 and the tailing factor was less than 1.3.

\section{Method validation}

Following the analytical method development, the method was validated following FDA and ICH guidelines [16,17] Standard procedures to evaluate required validation items were followed.

\section{Specificity}

Bank solvent samples were injected and no drugs were detected (Figure 1). The drug was unstable under alkaline conditions (Figure 2) and was degraded. The drug was degraded to about $81 \%$ under acidic conditions (Figure 3). In neutral conditions, risperidone was more stable when the drug was refluxed with water for 1 $\mathrm{h}$, and there was almost no degradation (Figure 4). The stability of the stock solution under conditions $\left(2\right.$ to $\left.8^{\circ} \mathrm{C}\right)$ was assessed by risperidone quantification and comparison with the freshly prepared standard solution (Figure 5). No remarkable change occurred in the stock solution response, in comparison to freshly prepared standard.

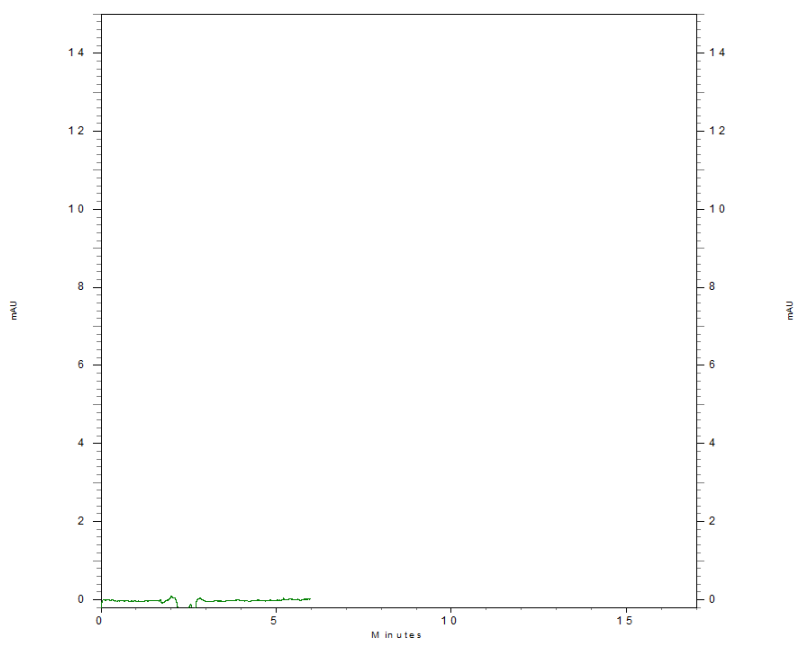

Figure 1: Chromatogram of Blank solvent.

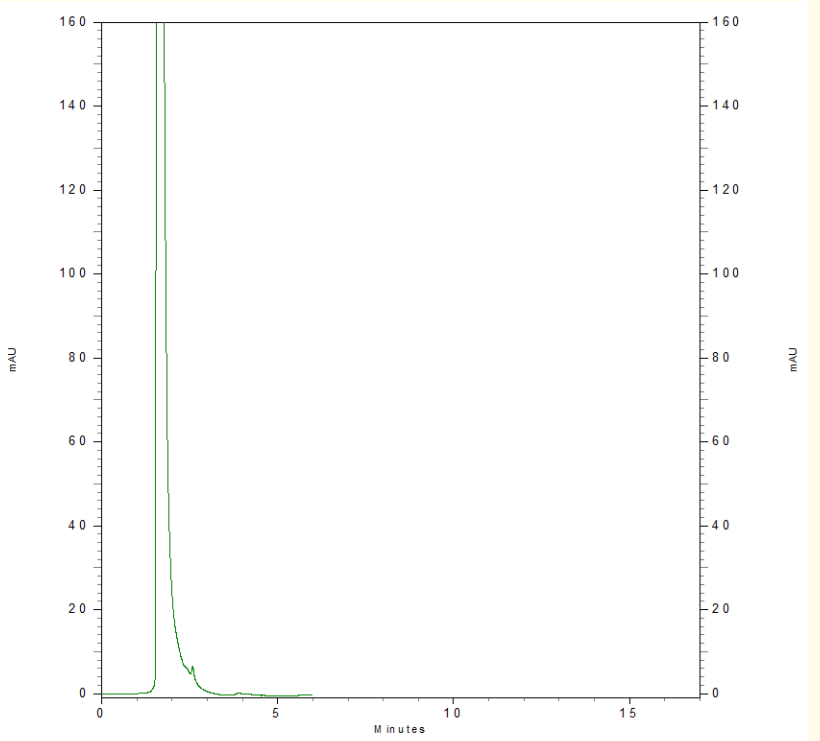

Figure 2: Chromatogram of Risperidone Stress $\mathrm{NaOH}$ 


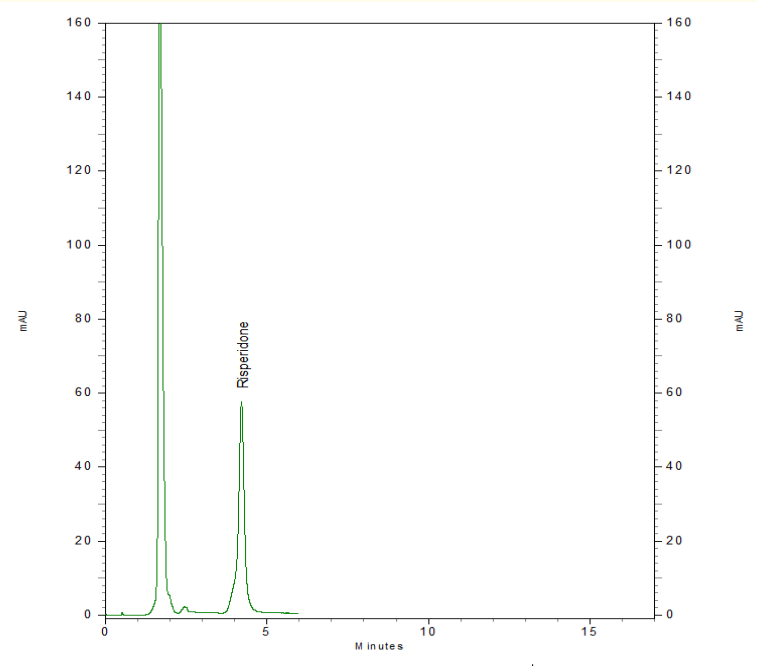

Figure 3: Chromatogram of Risperidone Stress HCL.

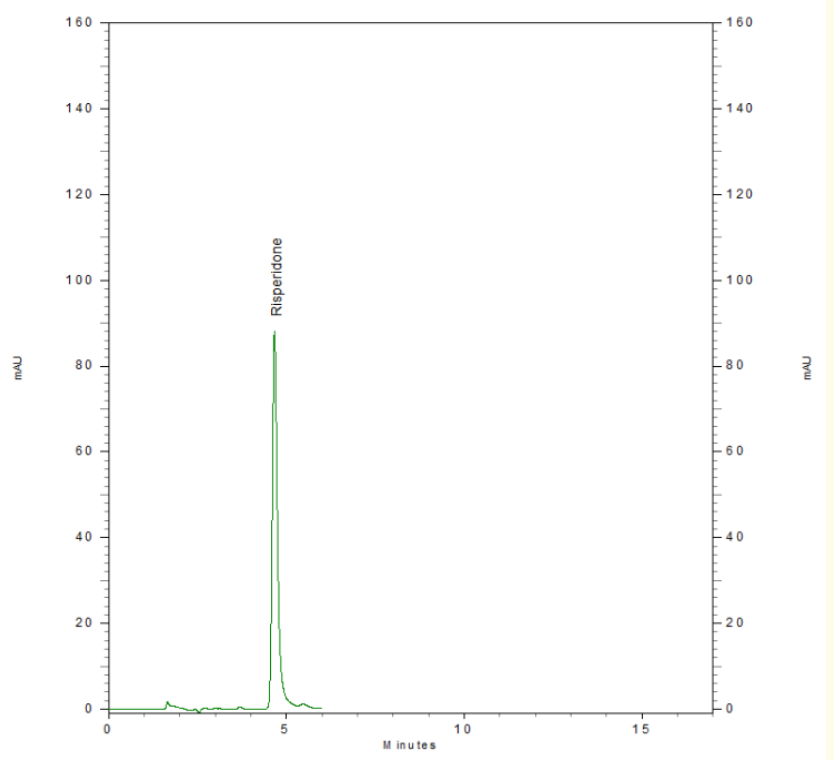

Figure 4: Chromatogram of Risperidone Stress Heat.

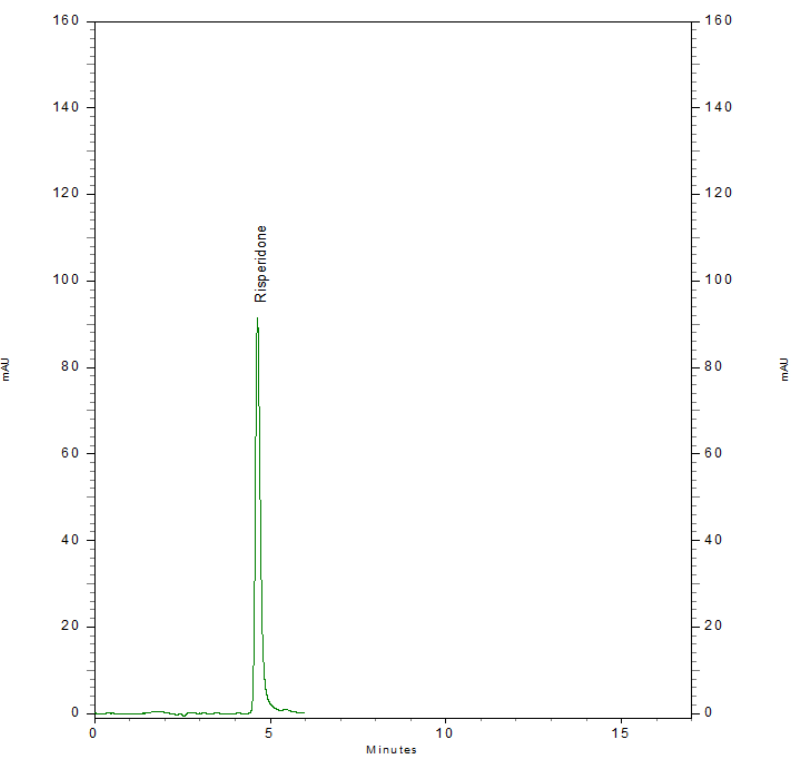

Figure 5: Chromatogram of Standard Risperidone.

All forced degradation samples were analyzed under the above HPLC conditions to monitor the homogeneity and purity of the risperidone peak. There was no interference with individual related substances, placebo and risperidone, thus providing a specific analytical method.

Linearity

Risperidone showed linearity from 0.2 to $6 \mu \mathrm{g} / \mathrm{ml}$ in USP medium and from 0.1 to $3.4 \mu \mathrm{g} / \mathrm{ml}$ in dissolution medium $\mathrm{pH} 1.2$, 4.5 , and 6.8 with (r2 $=0.999$ ) for HPLC. Linearity was assessed in triplicate by the determination of eight standard concentrations within range of 0.2 to $6 \mu \mathrm{g} / \mathrm{ml}$ using USP medium $0.1 \mathrm{NH} \mathrm{HCl}$ and within range of 0.1 to $3.4 \mu \mathrm{g} / \mathrm{ml}$ using media $\mathrm{pH} 1.2, \mathrm{pH} 4.5$ and $\mathrm{pH} 6.8$ as solvent. Peak areas of risperidone were plotted versus the concentration of risperidone $(\mu \mathrm{g} / \mathrm{ml})$ and linear regression analysis was conducted (Table 1). High correlation coefficient (r2) and low intercept CV\% value (less than 5\%) indicate validation of analytical method linearity. The resultant chromatogram demonstrated symmetrical and well-separated peak at $4.1 \mathrm{~min}$ (Figure 2). 


\begin{tabular}{|c|c|}
\hline Analyte & Risperidone \\
\hline Range & 0.2 to $6 \mu \mathrm{g} / \mathrm{mL}$ \\
\hline \multicolumn{2}{|c|}{ Linearity correlation equation } \\
\hline $\begin{array}{l}\text { At Dissolution medium } \\
(0.1 \mathrm{~N} \mathrm{HCl})\end{array}$ & $\begin{array}{c}Y=70477.4315800 x+ \\
140.6587692\end{array}$ \\
\hline Range & 0.1 to $3.4 \mu \mathrm{g} / \mathrm{mL}$ \\
\hline \multicolumn{2}{|c|}{ Linearity correlation equation } \\
\hline $\begin{array}{l}\text { At Dissolution medium } \\
\text { (pH1.2) }\end{array}$ & $\begin{array}{c}Y=72852.0412024 x+ \\
97.6381552\end{array}$ \\
\hline $\begin{array}{l}\text { At Dissolution medium } \\
(\mathrm{pH} 4.5)\end{array}$ & $\begin{array}{c}Y=53041.2955702 x- \\
193.3467121\end{array}$ \\
\hline $\begin{array}{l}\text { At Dissolution medium } \\
\text { (pH6.8) }\end{array}$ & $\begin{array}{c}Y=43505.4467602 x+ \\
99.7584606\end{array}$ \\
\hline \multicolumn{2}{|c|}{ Linearity correlation coefficient $\mathrm{R}^{2}$} \\
\hline $\begin{array}{l}\text { At Dissolution medium } \\
(0.1 \mathrm{~N} \mathrm{HCl})\end{array}$ & 0.9999312 \\
\hline $\begin{array}{l}\text { At Dissolution medium } \\
\text { (pH1.2) }\end{array}$ & 0.9999803 \\
\hline $\begin{array}{l}\text { At Dissolution medium } \\
(\mathrm{pH} 4.5)\end{array}$ & 0.9999906 \\
\hline $\begin{array}{l}\text { At Dissolution medium } \\
\text { (pH6.8) }\end{array}$ & 0.9999905 \\
\hline \multicolumn{2}{|l|}{ Mean Slope \pm SD } \\
\hline $\begin{array}{l}\text { At Dissolution medium } \\
(0.1 \mathrm{~N} \mathrm{HCl})\end{array}$ & $70477.432 \pm 292.578$ \\
\hline $\begin{array}{l}\text { At Dissolution medium } \\
(\mathrm{pH} 1.2)\end{array}$ & $72852.041 \pm 682.252$ \\
\hline $\begin{array}{l}\text { At Dissolution medium } \\
(\mathrm{pH} 4.5)\end{array}$ & $53041.296 \pm 9.081$ \\
\hline $\begin{array}{l}\text { At Dissolution medium } \\
(\mathrm{pH} 6.8)\end{array}$ & $43505.447 \pm 69.162$ \\
\hline \multicolumn{2}{|l|}{ Mean Intercept \pm SD } \\
\hline $\begin{array}{l}\text { At Dissolution medium } \\
(0.1 \mathrm{~N} \mathrm{HCl})\end{array}$ & $140.659 \pm 223.003$ \\
\hline $\begin{array}{l}\text { At Dissolution medium } \\
\text { (pH1.2) }\end{array}$ & $97.638 \pm 567.187$ \\
\hline $\begin{array}{l}\text { At Dissolution medium } \\
(\mathrm{pH} 4.5)\end{array}$ & $-193.347 \pm 94.999$ \\
\hline $\begin{array}{l}\text { At Dissolution medium } \\
(\mathrm{pH} 6.8)\end{array}$ & $99.758 \pm 90.253$ \\
\hline \multicolumn{2}{|l|}{ Standard error of slope } \\
\hline $\begin{array}{l}\text { At Dissolution medium } \\
(0.1 \mathrm{~N} \mathrm{HCl})\end{array}$ & 168.920 \\
\hline
\end{tabular}

\begin{tabular}{|l|l|}
\hline $\begin{array}{l}\text { At Dissolution medium } \\
\text { (pH1.2) }\end{array}$ & 393.898 \\
\hline $\begin{array}{l}\text { At Dissolution medium } \\
\text { (pH4.5) }\end{array}$ & 5.243 \\
\hline $\begin{array}{l}\text { At Dissolution medium } \\
\text { (pH6.8) }\end{array}$ & 39.931 \\
\hline Standard error of intercept & 128.751 \\
\hline $\begin{array}{l}\text { At Dissolution medium } \\
\text { (0.1N HCl) }\end{array}$ & 327.466 \\
\hline $\begin{array}{l}\text { At Dissolution medium } \\
\text { (pH1.2) }\end{array}$ & 54.848 \\
\hline $\begin{array}{l}\text { At Dissolution medium } \\
\text { (pH4.5) }\end{array}$ & 52.107 \\
\hline $\begin{array}{l}\text { At Dissolution medium } \\
\text { (pH6.8) }\end{array}$ & \\
\hline
\end{tabular}

Table 1: Linearity Results

Where, $n=3$, average of three determinations, SD $( \pm)$ : standard deviation.

\section{Precision}

Intra-day variations can be expressed in terms of CV\%. Values of CV\% in dissolution medium USP $(0.1 \mathrm{~N} \mathrm{HCl}), \mathrm{pH} 1.2,4.5$, and 6.8 have been shown to be less than or equal to $2 \%$, revealing good precision. The mean CV\% for dissolution medium USP $(0.1 \mathrm{~N} \mathrm{HCl})$, pH $1.2,4.5$, and 6.8 were $0.850,0.303,0.790$, and $0.083 \%$.

\section{Detection Limit (LOD) and quantitation limit (LOQ)}

The LOD and LOQ of the method were determined by the injection of gradually low concentrations of standard solutions using the HPLC method developed. The detection Limit for risperidone was $0.010,0.026,0.006$, and $0.007 \mu \mathrm{g} / \mathrm{mL}$ for dissolution media $0.1 \mathrm{~N} \mathrm{HCl}, \mathrm{pH} 1.2, \mathrm{pH} 4.5$, and $\mathrm{pH} 6.8$ respectively. The quantitation limit was $0.032,0.078,0.018$, and $0.02 \mu \mathrm{g} / \mathrm{ml}$ for dissolution media $0.1 \mathrm{~N} \mathrm{HCl}, \mathrm{pH} 1.2,4.5$, and 6.8 respectively.

\section{Assay (Potency) of risperidone}

The developed method was used for risperidone assay in the tablet formulations. Results were found out as mean \% recovery $100.113 \%$ for risperidone reference orally disintegrating tablet. The results indicating that the method is selective for the assay of risperidone with no interference from the inactive ingredients. 


\section{Content uniformity of risperidone}

The developed method was applied for content uniformity of risperidone in an orally disintegrating tablet dosage form. Results were found out as a mean recovery of $100.564 \%$. The acceptance value was 1.856 for risperidone reference orally disintegrating tablet.

\section{Dissolution of risperidone}

The developed method was used for dissolution testing of risperidone orally disintegrating tablet. Results were found out as a dissolution profile for mean percentage drug dissoluted of risperidone in Reference tablets. Results have shown that the reference product complies with the FDA and BCS Guidelines [18] and the United States Pharmacopeia Regulations (USP) [19].

The results of risperidone $2 \mathrm{mg}$ orally disintegrating tablet dissolution \% in $0.1 \mathrm{~N} \mathrm{HCl}$ (USP medium) after 5, 10, 15, 20, 30, 45, and 60 minutes were 77.894, 82.604, 86.179, 90.200, 93.794, 97.127, $99.258 \%$ respectively.

The results of risperidone $2 \mathrm{mg}$ orally disintegrating tablet dissolution \% in medium pH1.2 after $5,10,15,20,30,45$, and 60 minutes were 80.554, 83.985, 86.216, 88.166, 89.839, 91.673, 93.769\% respectively.

The results of risperidone $2 \mathrm{mg}$ orally disintegrating tablet dissolution \% in medium pH4.5 after $5,10,15,20,30,45$, and 60 minutes were 90.544, 92.959, 94.200, 94.965, 95.936, 96.540, 97.849\% respectively.

The results of risperidone $2 \mathrm{mg}$ orally disintegrating tablet dissolution \% in medium pH6.8 after $5,10,15,20,30,45$, and 60 minutes were $59.228,71.606,82.841,84.923,89.663,92.805,96.908 \%$ respectively.

Results of method validation, assay, and dissolution indicate that the method validation and drug product complies with the specified requirements and will therefore provide the required clinical benefit in the management of schizophrenia, bipolar mania, and autistic disorder associated irritability.

\section{Discussion}

It should be noted that the estimation and testing of risperidone in pharmaceutical products, including tablets, and the assessment of its in vitro performance, including dissolution using a validated methodology, are important for ensuring the therapeutic effectiveness of risperidone.

As shown previously, the clinical importance of risperidone as an antipsychotic drug in the treatment of schizophrenia, and bipolar mania with a better clinical effect than first-generation antipsychotics [1,2]. Besides, it improves autistic disorder associated irritability symptoms in children and adolescents, and has a good safety profile [1] And aid in managing dementia symptoms like aggression, psychosis, and agitation [4].

Many analytical methods have been developed for the quantification of risperidone in pharmaceutical products. An HPLC method was developed for the assessment of risperidone in tablet formulations. C18 250×4.6 mm, $5 \mu \mathrm{m}$ column was used. Solvent elution was in isocratic mode. The mobile phase of methanol: acetonitrile: 50 mM phosphate buffer (80: 10: $10 \mathrm{~V} / \mathrm{V} / \mathrm{V}$ ) was used at flow $1.3 \mathrm{ml}$ / min. UV detector wavelength was set at $234 \mathrm{~nm}$. The LOD and LOQ values were 0.5 and $0.99 \mathrm{ug} / \mathrm{ml}$ respectively [6].

Another validated stability-indicating assay method for risperidone was developed. Chromatography was achieved using C18 column $250 \mathrm{~mm} \times 4.6 \mathrm{~mm}$ and eluting solvent of methanol and acetonitrile (80: $20, \mathrm{~V} / \mathrm{V})$ at $1 \mathrm{ml} / \mathrm{min}$ flow rate. detection was performed at UV $280 \mathrm{~nm}$. The method showed linearity within the range of 10 to $60 \mu \mathrm{g} / \mathrm{ml}$, and r2 0.998. LOD $1.79 \mu \mathrm{g} / \mathrm{ml}$ and LOQ $5.44 \mu \mathrm{g} / \mathrm{ml}$ [9].

The analytical method for risperidone determination was developed as follows. Chromatography was performed using C8 DB column $25 \mathrm{~cm} \times 0.46 \mathrm{~cm}, 5 \mu \mathrm{m}$ p.s., at $40^{\circ} \mathrm{C}$ and the eluting solvent ratio of $100 \mathrm{mM}$ amm. acetate $\mathrm{pH} 5.5$ : methanol (40:60 V/V) and $1 \mathrm{ml} / \mathrm{min}$ flow rate, and $274 \mathrm{~nm}$ UV detection wavelength. Method linear was from 4.0 to $275 \mu \mathrm{g} / \mathrm{ml}$, and r2 0.9998. LOD $0.48 \mu \mathrm{g} / \mathrm{ml}$ and LOQ $1.59 \mu \mathrm{g} / \mathrm{ml}$. The precision was below $3.27 \%$, while accuracy was 99.00 to $101.12 \%$ [14].

Another HPLC method was developed for the estimation of risperidone in bulk and dosage forms. C18 column was used with an eluting solvent of water: methanol 35: $65 \mathrm{~V} / \mathrm{V}$ (PH 5.5). wave length of $276 \mathrm{~nm}$ was used for detection. The method demonstrated good linearity $\mathrm{r}^{2}$ 0.999. LOD $7.53 \mu \mathrm{g} / \mathrm{ml}$ and LOQ $2.48 \mu \mathrm{g} / \mathrm{ml}[15]$.

The HPLC - UV method used in this study was convenient and of highly sensitive, specific, precise and accurate. Materials and re- 
agents used for analysis are common, suitable and available, such as C8 column $150 \mathrm{~mm} X 4.6 \mathrm{~mm}$, TFA and Acetonitrile. Eluting solvent was isocratically pumped, and the total run time was $5.1 \mathrm{~min}$ utes. This allows analysis of up to 250 samples per 24 hours. The method showed an advantage over the reported methods regarding the Lower limit of quantitation [6,9,13-15].

The standard curve using $0.1 \mathrm{~N} \mathrm{HCl}$ as a solvent showed linearity over the range of 0.2 to $6 \mu \mathrm{g} / \mathrm{ml}$ and LOQ of $0.032 \mu \mathrm{g} / \mathrm{ml}$. And using $\mathrm{pH} 1.2,4.5$, and 6.8 media as a solvent was linear over the range of 0.1 to $3.4 \mu \mathrm{g} / \mathrm{ml}$ and LOQ was $0.078,0.018$, and $0.02 \mu \mathrm{g} / \mathrm{ml}$ respectively. $r^{2}$ was equal to 0.999 , accuracy of the results was within the range of 98 - 102\%, and analytical precision was below 2\% which is following FDA and ICH guidelines $[10,11]$. The intercept value standard deviation was below 5\%, number of theoretical plates higher than 4000, tailing factor below 1.3, and so it can be used to determine risperidone in pharmaceutical formulations.

The method is appropriate for use in the routine quality control of distributed risperidone products in the market in order to guarantee adherence of distributed products under various storage circumstances in hospitals and pharmacies with specifications, absence of probable degradative product formation, and reduction of active ingredient quantity in the dosage form, and safe administration of risperidone products with no side effects, and avoiding lack of clinical efficacy.

\section{Conclusion}

The HPLC analytical method developed for the quantification of risperidone in pharmaceutical formulations enables a specific, accurate and precise analysis of risperidone. The developed analytical method has shown sufficient sensitivity for quantification of risperidone in pharmaceutical formulations and therefore can be used for routine analysis, quality control and stability studies of pharmaceuticals, thereby guaranteeing safe and effective management of schizophrenia.

\section{Conflicts of Interest}

The authors declare no conflict of interest.

\section{Bibliography}

1. Scott LJ and Dhillon S. "Risperidone: a review of its use in the treatment of irritability associated with autistic disorder in children and adolescents". Paediatric Drugs 9.5 (2007): 343354 .

2. Madaan V., et al. "Clinical utility of the risperidone formulations in the management of schizophrenia". Neuropsychiatric Disease and Treatment 7 (2011): 611-620.

3. Grant $\mathrm{S}$ and Fitton A. "Risperidone. A review of its pharmacology and therapeutic potential in the treatment of schizophrenia”. Drugs 48.2 (1994): 253-273.

4. Yunusa I and El Helou ML. "The Use of Risperidone in Behavioral and Psychological Symptoms of Dementia: A Review of Pharmacology, Clinical Evidence, Regulatory Approvals, and Off-Label Use". Frontiers in Pharmacology 11 (2020): 596.

5. Z Song and C Wang. "Sensitive chemiluminescence assay for risperidone in pharmaceutical preparations". Journal of Pharmaceutical and Biomedical Analysis 36.3 (2004): 491-494.

6. S Bladania., et al. "RP-HPLC estimation of risperidone in tablet dosage forms". Indian Journal of Pharmaceutical Sciences 70.4 (2007): 494-497.

7. SK Patel and N J Patel. "TLC determination of amitriptyline $\mathrm{HCl}$, trifluoperazine $\mathrm{HCl}$, risperidone and alprazolam in pharmaceutical products". Chromatographia 69.3-4 (2009): 393-396.

8. A Goyal and I Singhvi. "Visible spectrophotometric determination of aceclofenac in tablet formulation". Asian Journal of Chemistry 18.4 (2006): 3157-3159.

9. Zarna R Dedania., et al. "Stability Indicating HPLC Determination of Risperidone in Bulk Drug and Pharmaceutical Formulations". International Journal of Analytical Chemistry 6 (2011).

10. ICH HARMONISED TRIPARTITE GUIDELINE. Validation of Analytical Procedures: Text and Methodology Q2 (R1) (2005).

11. U.S. Department of Health and Human Services Food and Drug Administration, Guidance for Industry, Analytical Procedures and Methods Validation for Drugs and Biologics (2015).

12. U.S. Department of Health and Human Services Food and Drug Administration, Guidance for Industry Waiver of in Vivo Bioavailability and Bioequivalence Studies for Immediate-Release Solid Oral Dosage Forms Based on a Biopharmaceutics Classification System (2017). 
13. Risperidone orally disintegrating tablets, USP35.

14. Ashour S and Kattan N. "Sensitive method for the quantitative determination of risperidone in tablet dosage form by highperformance liquid chromatography using chlordiazepoxide as internal standard". International Journal of Biomedical Science 9.2 (2013): 91-97.

15. Bhavana A Kokane., et al. "RP-HPLC Method Development and Validation for Estimation of Risperidone in Bulk and Dosage Forms". International Journal of Pharmaceutical Sciences Review and Research 54.1 (2019): 29-32.

\section{Assets from publication with us}

- Prompt Acknowledgement after receiving the article

- Thorough Double blinded peer review

- Rapid Publication

- Issue of Publication Certificate

- High visibility of your Published work

Website: www.actascientific.com/ Submit Article: www.actascientific.com/submission.php Email us: editor@actascientific.com

Contact us: +919182824667 